\title{
Gândavo: da objetividade e de suas traições
}

Francisco Ferreira de Lima (UEFS)

Ao defrontar uma paisagem nova, em caráter inaugural, ensina Francis Affergan (1987), o sujeito é tomado, ainda que não o queira, por uma sensação que o antropólogo francês chama de cintilação do real.

Como se sabe, o olho é só um elemento de um processo complexo de apreensão do real. Parte significativa desse complexo é o acervo de conceitos e imagens através do qual decodificamos os feixes de luz captados pelo olhar. E tal decodificação opera por um mecanismo de enquadramento do real observado, a que se impõe uma espécie de moldura, ou, como se diz hoje, um foco. Emoldurados, isto é, localizados, identificados e relativizados no interior do acervo - tarefa realizada com mais rapidez e precisão que por qualquer computador jamais inventado -, aqueles feixes de luz transformam-se em conhecidos e familiares contornos do mundo. Tão automática é essa operação na vida cotidiana que sequer nos damos conta de sua complexidade - e se nos déssemos, em nada nos ajudaria.

Se é assim com a vida cotidiana, muito diferente o será na vida extraordinária, aquela vivida na ausência da rotina, aquela que precisa construir, a cada coisa vista, uma referência, base sem o que perdemos o nosso fundamental sentido de orientação no mundo, cuja conseqüência imediata é uma mistura de deslumbramento, desespero e desamparo, não necessariamente nessa ordem.

Com a diminuição do tamanho do mundo, com as imagens de TV que chegam às nossas casas oriundas dos lugares mais remotos, sejam as do tsunami na Malásia, as do massacre de Rwanda ou as das mulheres-girafas da Indonésia, que alongam o pescoço para ficar mais bonitas, a possibilidade de viver essa experiência radical é cada 
vez mais difícil, posto nos ser oferecido, no máximo, o reconbecimento do mundo, que ele está quase todo desvestido. Quase todo, observe-se, pois ainda há cantos e recantos à espera - poucos e não por muito tempo! - dos renitentes retardatários.

Cintilação do real, como a quer Affergan, só pode ser vivida na sua intensidade numa viagem primeira, inauguradora, aquela em que o sujeito se acha frente a frente com um mundo irredutível ao seu aparelho mental. Incapacitado por uma espécie de desconexão entre o olhar e seu repertório de conceitos e imagens, agora coisas alheias uma à outra, o sujeito já não consegue emoldurar o real observado. Este, agora, é só um excesso, uma desmedida. Desligado da tomada, o olhar transforma-se de pontade-lança em lança inteira, uma vez que não há respostas ao envio de suas mensagens. Acostumado a ser parte e agora sendo o todo, soberanamente autônomo, o olhar deleita-se ante o que vê, pois tudo que vê transforma-se numa festa de luz e cores, da qual está excluído o significado - sensação muito semelhante àquela que dizia viver aquele poeta de papel chamado Alberto Caeiro, a que dava o nome de pasmo inicial. Sem significado, ou seja, sem conexão com o aparelho mental, o mundo é luz, é cor, é brilho, é vertigem, é, numa palavra, cintilação.

Embora intensa e gostosamente vivida, é experiência curta, a da cintilação, que o poder onipresente do conceito, como os escoteiros, está sempre alerta. E é curta porque, sob seu efeito, o sujeito não pode julgar, não pode comparar. Daí o deslumbramento transformar-se em desamparo, e o desamparo em desespero, porque sem julgar, sem comparar, o sujeito perde seu principal traço de humanidade. Aliás, se quiséssemos uma dessas fórmulas que se pretendem sintéticas, bem poderíamos dizer que viver é julgar.

E para julgar é preciso recortar, isto é, emoldurar o mundo, para, a partir daí, relativizar, localizar e identificar o nosso lugar nele, em oposição ao lugar do outro. Com o fim desse processo, que vai do deslumbramento à construção do contorno, a estranheza radical estará domada, assimilada, embora quase nunca compreendida - quase sempre para desgraça de quem calhou ser o objeto daquele olhar.

Desde Heródoto, pelo menos, conhecemos relatos de experiências de viagens, nos quais, naturalmente, podem ser observadas descrições deslumbradas de encontros inaugurais. Mesmo ao longo da Idade Média, que viajou mais pelo ouvido que pelos pés, podem-se encontrar outros relatos de maravilhas, dentre os quais o emblemático de Marco Pólo. Mas a partir da expansão marítima ibérica, sobretudo a parte relativa ao chamado Novo Mundo, produziu-se um relato de viagem do qual se pode dizer fruto efetivo de um encontro inaugural em seu sentido mais lato, pois nada do que se encontrou estava pré-visto, como se dava com o Extremo Oriente, secular- 
mente inventado e reinventado pelo imaginário europeu, que o encheu de espantosas maravilhas, autorizando que se visse o que ainda não se tinha visto.

Disso resultou, por exemplo, o infame trocadilho com que o pobre do Mendes Pinto foi injustamente agraciado. Após sua longa Peregrinação, ficou conhecido por Fernão, Mentes? Minto! Mostrei num longo texto a ele dedicado (LIMA, 1998) que não se tratava de mentira, mas de um descompasso entre o que se via pela primeira vez e o modo pelo qual isso deveria obrigatoriamente ser enquadrado.

No caso do Novo Mundo, assim chamado exatamente para identificar uma desmedida radical, exigiu-se do viajante guerra feroz contra a flutuação de significados, pois os que trazia de nada serviam ante tanta novidade. E a novidade nela mesma não era capaz de produzir aqueles outros necessários a sua decodificação, o que o deixava em estado de atordoada perplexidade, "pasmado de ver", na fórmula de Mendes Pinto (1983).

Então, como diz Todorov (1983), a primeira batalha a ser travada nesses alegres e tristes trópicos tinha por arma não a espada - esta só viria a ser usada com entusiasmo depois - mas o código. Antes de matar, era preciso, primeiro, conhecer. Mas antes de conhecer, não há como fugir disso, era o viajante obrigado a ver. Quanto a isso, à vertigem da cintilação, nenhum deles escapa.

Arriscaria dizer, portanto, que Sérgio Buarque de Hollanda (1992) só tem razão em parte, ao dizer na abertura de seu precioso estudo que "o gosto da maravilha e do mistério, quase inseparável da literatura de viagens nos grandes descobrimentos marítimos, ocupa espaço singularmente reduzido nos escritos quinhentistas dos portugueses sobre o Novo Mundo." De uma parte, ele tem toda razão: não encontraremos nenhum Bernal Diaz de Castilho ou - para ficar com um português dos grandes nenhum Fernão Mendes Pinto a descrever descabeladas maravilhas do Brasil.

Mas - e de outra aqui ele não tem - é bom não esquecer que a maravilha, se bem em doses homeopáticas, acompanha pari passu a pragmática descrição do viajante português. Aliás, creio já ter demonstrado com algum vagar (LIMA, 2000; LIMA 2001a) alguns exemplos cabais disso, ao abordar, nessa perspectiva, um dos autores fundamentais do século XVI, Gabriel Soares de Sousa.

"Sesudo" português da segunda metade de quinhentos, verdadeiro homem do Renascimento, que tudo viu, mediu e calculou, Soares de Sousa não deixou, no entanto, de tratar em sua descrição do Brasil de cobras que, depois de terem toda sua carne comida pelos urubus, começavam lentamente a renascer e em pouco tempo voltavam ao que eram; de outras cobras que engoliam índios inteiros, e delas era possível sair-se vivo se se levasse um facão com o qual se cortasse seu "lombo" - habilidade que os 
índios logo desenvolveram; de bichos que, apesar de cortados em ínfimos pedaços, não morriam nunca, como o buijeja, sem falar em sua minuciosa descrição do Ipupiara, o "monstro marinho", que matava com abraços e beijos, comedor de extremidades, de preferência narizes e "naturas", que incendiou a imaginação colonial brasileira ou, ainda, na Vupabuçu dos índios, uma grande lagoa, ora situada na cabeceira do São Francisco, ora em plena selva amazônica, de onde brotava ouro em pó, cuja matriz radicava na fonte do paraíso.

Além de Soares de Sousa, em outro texto ainda (LIMA, 2004), analisei o progressivo deslumbramento de Caminha em relação aos primeiros habitantes do Brasil, que o fizeram supor ter encontrado um símile do paraíso terreal - senão o próprio. Não será diferente se lermos com atenção o Padre Fernão Cardim, o Frei Vicente do Salvador e tantos outros.

Porque involuntário, portanto, nenhum viajante está imune a "ocupar o gosto" no ver, independentemente de quão grande ou pequena seja a sua fantasia. Por mais que se esforce em evitá-lo, ele lá estará nos interstícios da sua (sonhada) objetividade total. A diferença, que talvez tenha escapado ao eminente estudioso brasileiro, é que alguns viajam em busca do exercício desse gosto, ao passo que outros o fazem contra ele. Tal é o caso da maioria dos viajantes portugueses, menos interessados no "gosto" de ver do que em praticar aquilo que chamei (LIMA, 2001b) de retórica da sedução, mecanismo pelo qual a escrita funciona como um meio e não como um fim em si mesmo. Acentuam-se as coisas boas da terra e, de preferência, escondem-se as más, de modo a atrair a atenção do rei para protegê-la dos perigos de invasão e, ao mesmo tempo, despertar o entusiasmo do colono que se disponha a trocar o Reino, belo e familiar, mas pleno de escassez, pela Colônia, desconhecida e estranha, mas cheia de fartura - como no paraíso.

No caso dos viajantes portugueses do século XVI um dos exemplos mais emblemáticos de recusa ao gosto de ver, isto é, de pôr sua escrita "a serviço", é o de Pero de Magalhães de Gândavo, autor do Tratado da província do Brasil, ou melhor, Tratado da terra do Brasil, isto é, História da província Santa Cruz a que vulgarmente chamamos Brasil, da qual, não bastassem as duas anteriores, se conhecem duas versões. (Ou seja, para começo da história, Gândavo é quatro vezes autor de um mesmo texto!).

As razões para tantas (re)escrituras, objeto deste trabalho, estão diretamente ligadas a essa recusa do gosto de ver.

Antes, porém, tratemos um pouco do homem.

Gândavo é o pioneiro de uma longa e nobre linhagem de descritores do Brasil. Como, todavia, é próprio daqueles idos tempos, é incerta sua origem. Supõe-se seja 
ele descendente de flamengos, que habitavam Gand, Gandavum (em latim), cidade situada na região de Flandres, e que a trocaram por Braga, norte de Portugal.

Sabe-se que foi membro da corte de D. Sebastião, onde desempenhava as funções de "Moço de Câmara", uma espécie de Ajudante de Ordens, como se diz no exército. E que, além disso, trabalhou como copista na Torre do Tombo, nos termos técnicos da época, "que trasladava livros". Sabe-se ainda, mas não muito mais, que foi nomeado "Provedor da Fazenda" em Salvador, mas não há registro de que tenha assumido tal cargo.

Incerta ainda é a época de sua estada no Brasil, motivo de interminável controvérsia entre filólogos e historiadores, a maioria dos quais, contudo, prefere situá-la entre 1558 e 1572, tempo que corresponde ao Governo de Mem de Sá, a cuja morte do filho ele faz referência.

Típico renascentista, Gândavo é homem de gabinete e de aventura. Quanto ao primeiro aspecto, é autor de umas Regras que ensinam a maneira de escrever e ortographia da lingua portuguesa, publicadas em 1574, pela mesma "Ophicina” de Antonio Gonsalvez. O mesmo editor que, dois anos antes, dera a público Os Lusíadas, de Luiz de Camões, de quem Gândavo era admirador e amigo, e dois anos depois publicaria sua versão definitiva da História da província Santa Cruz a que vulgarmente chamamos Brasil.

Mas era um renascentista especial, com "ampla visão de mercado", como se diria atualmente. Enquanto os grandes do século XVI português escreviam para poucos, para a Corte, para os pares, orgulhosos da semelhança entre o português e o latim, Gândavo sonhava com a difusão da informação em larga escala. Embora professor de latim, no que diz respeito as suas Regras..., posteriores tanto à gramática de Fernão de Oliveira, publicada em 1536, quanto à de João de Barros, de 1540, ele pretendia com elas tão somente ajudar a quem não sabia "que coisa é nome e que coisa é verbo" - e não aos que já tinham "inteligência em Latim".

Seu objetivo foi atingido em cheio, pois, como informam Sheila Hue e Ronaldo Menegaz (2004:16) ${ }^{1}$ no prefácio da bela edição da Historia da provincia Santa Cruz a que vulgarmente chamam Brasil por eles organizada - utilizada ao longo deste estudo -, seu livrinho de regras ortográficas transformou-se na mais popular gramática do século XVI em Portugal, vindo a merecer, nada mais, nada menos, três edições ao longo daquele século. E com o mesmo objetivo foi escrita a História... Não para intelectuais, mas para o leitor comum, menos interessado em torneios frasais que em vida real.

Quanto ao outro aspecto, é o viajante curioso das novidades do mundo, tanto para vê-las de perto quanto para "dar novas particullares destas partes", nunca antes sabidas, de modo a incentivar seus conterrâneos depauperados a trocar a pobreza em 
que viviam no reino pela fartura das novas terras. Por isso, embora não se saiba ao certo a época em que andou pelo Brasil, são hoje pouco prováveis as hipóteses de que não o tenha feito. Uma das razões para duvidar delas é, como se verá adiante, a vivacidade e o encantamento com o pormenor com que descreve aspectos da colônia, só possíveis numa visão in loco.

Ao conjunto de incertezas que cerca a vida de Gândavo, soma-se o desconhecimento do local e data de sua morte. Mas como ele bem o planejara, renascentista completo que era, passa o homem, fica a obra.

A História da provincia Santa Cruz a que vulgarmente chamamos Brasil confunde-se com a vida do seu autor. Gândavo ocupou dez anos de sua vida entre a primeira e a versão definitiva, finalmente impressa em 1576, do que bem se poderá inferir, como fazem os organizadores da edição (2004, p. 19), que esse texto se transformou "no mais importante projeto da sua vida."

Que obsessão o movia para levá-lo a reescrever tantas vezes o seu texto? É o que tentarei responder ao longo deste ensaio, mas posso adiantar a resposta como hipótese: trata-se de um esforço - meio inútil, já o sabemos - de anular toda e qualquer possibilidade de deslumbramento ante um real que se deve apreender com total objetividade, visto que o texto se quer como um pretexto: seduzir, com informação objetiva, o reinol inseguro, amedrontado com tantas narrativas de prodígios e sortilégios que o século XVI banalizou. Manter-se nesse diapasão é correr o risco de ver o projeto naufragar, por semelhança a tantos outros. Em meio a tanto mistério, Gândavo enfatizará precisão e objetividade totais. Assim, ao invés de igualar-se aos seus contemporâneos, ele pretende-se diferente deles. E para tanto, luta dez longos e incansáveis anos para consegui-lo - no limite do que, sem saber, lhe era permitido.

Nas primeira parte deste texto, mostro as estratégias utilizadas por Gândavo para atingir seu objetivo; na segunda como tal objetivo não pôde - nem pode! - ser totalmente atingido.

Começo por um dos exemplos mais significativos encontrados em seu texto, a descrição da jibóia, como, aliás, bem o notaram Hue e Menegaz (2004, p. 104). No Tratado, essa cobra é mostrada como uma entidade fantástica, simulacro do mito da fênix, versão preferida pelos que vieram depois, como Gabriel Soares de Sousa, por exemplo.

Há nestas partes muitos bichos muito ferozes e peçonhentos, principalmente cobras de muitas castas e de nomes diversos. Umas há tão grandes e tão disformes que engolem um veado todo inteiro, e afirmam que tem esta cobra tal qualidade que depois de o ter comido arrebenta pela barriga e apodrece com a cabeça e a ponta do rabo sãs; e tanto que desta maneira fica torna pouco a pouco a criar carne nova até que se cobre 
outra vez da mesma carne tão perfeitamente como dantes: isto viram e experimentaram muitos índios e moradores da terra, a estas chamam pela língua dos índios giboioçu $(T B, 31)$.

A História traz uma descrição da jibóia na qual tais elementos fantásticos desapareceram por completo. Não se dá sequer o nome do bicho. Tudo é recoberto por ampla generalização. Em se tratando de uma terra estranha, muitos e estranhos bichos devem haver ali. E ponto. "Há também pelo mato adentro cobras mui grandes, e de muitas castas, a que os índios dão diversos nomes conforme as suas propriedades. Umas há na terra tão disformes de grandes que engolem um veado ou qualquer outro animal semelhante, todo inteiro" (HSC, 103).

Mas tal sobriedade de apresentação parece deixar Gândavo ainda apreensivo, uma vez saber faltar a moldura ao reinol para enquadrar tamanha estranheza. E não custa repetir que o imaginário europeu estava sobrecarregado de tanta maravilha, boa parte dela já no limite da exaustão, companhia da qual Gândavo parece esquivar-se. E para dela, da companhia, distinguir-se, é fundamental manter-se no plano do crível. Se não há a moldura, então é preciso construí-la. É o que Gândavo se obriga a fazer. A comparação é seu único instrumento.

E isto [da jibóia] não é muito para espantar, pois vemos que nesta nossa pátria há hoje em dia cobras bem pequenas que engolem uma lebre ou coelho da mesma maneira, tendo um colo que à vista parece pouco mais grosso que um dedo, e quando vem a engolir estes animais alarga-se e dá de si de maneira que passam por ele inteiros e assim os estão sorvendo até os acabarem de meter no bucho, como entre nós é notório. Quanto mais estas outras de que trato, que por razão de sua grandeza fica parecendo a quem as viu menos dificultoso engolirem qualquer animal da terra, por grande que seja (HSC, 104).

Relativizados os tamanhos dos lugares, das cobras e de suas presas possíveis, pode ocorrer de a informação ganhar credibilidade. Melhor, então, para evitar riscos futuros, pois talvez não haja moldura bastante, deixar de fora cobras ainda mais estranhas. Tal é o caso dessas estranhíssimas cobras com asas abaixo elencadas, das quais Gândavo parece querer descomprometer-se com este "também afirmam alguns homens”. Mas sem o conseguir de todo, que sua estranheza o obriga a referi-las:

Outras há muito maiores e mais peçonhentas, doutra casta diferente, são tão grandes em tanto extremo que apenas dezesseis índios podiam levar uma que mataram junto da costa entre os portugueses; a esta cobra chamam surucucu (...). Também afir- 
mam alguns homens que viram serpentes nesta terra com asas muito grandes e espantosas, mas acham-se raramente $(T B, 32)$.

Para evitar problemas dessa ordem, Gândavo encontra-se freqüentemente às portas do limite do indizível, tal a acrobacia verbal a que se vê obrigado a exercitar. É o caso, por exemplo, da descrição do tatu, um dos animais, por sua estranheza, prediletos no imaginário europeu, que com ele se familiarizou através de muitas gravuras. O tatu de Gândavo é um animal compósito, um pouco ao modo desses jogos de montar um pretenso ser humano perfeito a partir de membros de várias pessoas, cujo resultado é sempre um desastre. Ante a ausência completa de moldura, como se observa na introdução, a única possibilidade é a comparação, por partes, do bicho:

Outros há também nestas partes muito para notar, diferentes de todos os outros animais (a meu juízo) que quantos até agora se tem visto. Chamam-lhes tatus e são quase tamanho como leitões, têm um casco como de cágado, o qual é repartido em muitas juntas, como lâminas, e arranjado de maneira que parece totalmente um cavalo armado. Tem um rabo comprido todo coberto do mesmo casco; o focinho é como de leitão, ainda que um tanto mais delgado, e não botam fora do casco mais que a cabeça. Tem as pernas curtas, e criam-se em covas como coelhos. A carne desses animais é a melhor e a mais estimada que há nesta terra e tem o sabor quase como de galinha (HSC, 95).

Observe-se que para construir a imagem do tatu foi necessário compará-lo a cinco outros animais: o leitão (duas vezes), o cágado, o cavalo armado, o coelho e, por fim, a galinha. É de perguntar: de síntese tão esquisita, que imagem pode efetivamente ser produzida? É difícil a resposta. Mas o objetivo é alcançado, uma vez que o teor de estranheza é cercado pela quantidade de comparações possíveis. O resultado, ainda que improvável, é que, não sendo igual a nenhum daqueles animais em particular, o tatu é fronteiriço, em cada uma de suas partes, a cada um deles, devendo ser pensado como um mosaico.

Com esses poucos exemplos, tentei demonstrar como Gândavo se esforçou para cumprir seu propósito de apresentar objetivamente a realidade brasileira. Diminuiu aqui, acrescentou ali, enfatizou mais adiante, mas, infelizmente, porque para além de sua vontade, o deslumbramento o perseguiu com feroz tenacidade, de cuja perseguição nem sempre o pobre homem escapou ileso. Por mais que se esquivasse do seu assédio, do começo ao fim do texto podemos flagrar a insinuação do deslumbramento, obrigando ao reagenciamento de energia para impedir o naufrágio da objetividade.

Não era para menos. Ante tanta maravilha, não parece haver cera bastante para pôr no ouvido dos marinheiros nem corda bastante para amarrar-se ao mastro, como 
fez aquele astuto navegador do "mar com fim", em sua longa viagem de volta à casa, disposto a sobreviver à mágica do canto da sereia. E já no prólogo, como já o mostramos, Gândavo desculpa-se antecipadamente, caso venha a falhar em seu projeto de objetividade:

...porque a terra é tal e tão favorável aos que a vão buscar, que a todos agasalha e convida com remédio, por mais pobres e desamparados que sejam. E também há nela coisas dignas de grande admiração, e tão notáveis, que pareceria descuido e pouca curiosidade nossa não fazer menção delas em algum discurso (HSC, 38).

Para seu projeto de retórica da sedução, lastreado em objetividade, a primeira parte do trecho era bastante. Se o que se pretende é apenas atrair o colono, já há informação bastante, diria mesmo demasiada, uma vez que, como já disse, essa idéia da terra como remédio parece apontar para uma promessa bem além do mundo real, um lugar de cura, alheio à dor.

A segunda parte, porém, introduz o efeito do deslumbramento, a partir dessas “coisas notáveis, dignas de admiração". Aí, já não há verdade histórica nem objetividade capazes de resistir ao apelo soberano do olhar. Que será vigiado permanentemente, como bem mostra o processo de escritura e re-escritura do texto, tudo para apagar os vestígios desse olhar festivo, que se rende gostosamente ao que vê, pondo em risco o projeto maior. Mas ainda que sob controle, o olhar vê e se deslumbra. Senão vejamos.

O capitulo dois, por exemplo, "Em que se descreve o sítio e as qualidades desta província" é, por fugir à diacronia, um prato cheio para flagrarmos algumas dessas traições. A primeira é, poderíamos dizer, da ordem do fantástico:

E pela [banda] do ocidente [o Brasil] confina com as altíssimas serras dos Andes e faldas do Peru, as quais são tão soberbas sobre a terra que se diz terem as aves trabalho em as passar. E até hoje um só caminho foi achado pelos que vêm do Peru a esta província, e este é tão agreste, que ao passá-lo perecem algumas pessoas, caindo do estreito caminho, e vão parar os corpos mortos tão longe dos vivos, que nunca mais os vêem, e nem podem, ainda que queiram, dar-lhe sepultura (HSC, 49).

Difícil escolher entre as duas possibilidades a mais espantosa, a de causar mais "admiração": se essas serras cuja altura é capaz de dificultar o vôo do pássaro, se esse íngreme caminho que leva à morte, verdadeiro círculo do inferno virgiliano, do qual, pior ainda, não se pode nunca voltar - nem mesmo depois de morto. E Gândavo, tão 
cioso de medidas e quantidades em outras partes de seu texto, não parece nem um pouco preocupado em averiguar a veracidade de tal informação, que transmite ao leitor, tal e qual, sem hesitar. O artifício lingüístico de que se vale é claro: ao utilizar o "que se diz", Gândavo põe o depoimento no nível do anonimato, fazendo-o funcionar como um fragmento solto de informação a circular como verdade consabida, o que o isenta de comprometimento. Não é ele quem vê. Não é ele quem o diz, diz-se que. E basta.

Mas não basta. O que se espera de um homem cioso da objetividade é que a tenha como a mestra suprema, sempre, a não ser que não possa fazê-lo. E é precisamente esse o caso. Trata-se de um alargamento da fronteira do prodigioso, que se vai empurrando para o limite do desconhecido. No Brasil, garante Gândavo, não há serra dessa envergadura - "destes e doutros extremos semelhantes carece esta província de Santa Cruz" (HSC, 49) - mas, no Peru, que parece tão distante quanto o Extremo Oriente, quem pode garantir? Dižse que. E o mundo, afinal, é sempre maior e mais misterioso que supomos, verdade que seu amigo Camões cunharia no belo par de versos "cousa há i que passam sem ser cridas / e cousa cridas há sem ser passadas". Assim o prodígio vai-se deslocando no tempo e no espaço, deixando atrás de si um rastro fantástico de mistério, miragem a atrair o desejo humano por estranhas novidades. Se o olhar desveste o conhecido, a imaginação reveste o desconhecido, pois há muito mais coisas entre o céu e a terra...

Se, entretanto, não possui esses extremos, as terras de Santa Cruz possuem elementos de outra natureza, capazes de impressionar o mais descrente de todos os descrentes, pois, fosse outra a circunstância, dir-se-ia estar ante uma reprodução do paraíso terreal:

Esta província é á vista mui deliciosa e fresca em grã maneira; toda ela esta vestida de mui alto e espesso arvoredo, regada com as águas de muitas e mui preciosas ribeiras de que abundantemente participa toda terra, onde permanece sempre a verdura com aquela temperança da primavera que cá nos oferecem os meses de abril e maio. E isto faz não haver lá frios, nem ruínas de inverno que ofendam suas plantas, como cá ofendem as nossas. Enfim, que assim se houve a natureza com todas as coisas desta província e de tal maneira se comediu na temperança dos ares, que nunca nela se sente frio nem quentura excessiva (HSC, 51).

O topos do paraíso terreal é o mais comum, dentre todos os outros empregados nos relatos de viagens do século XVI - e, bem se poderia dizer, de todos os séculos anteriores. Não é mero artifício retórico, como à primeira vista poderia parecer. Ao 
contrário, é uma lacuna a ser preenchida. Ao longo dos séculos, nunca se perdeu a esperança de tal reencontro, do homem com o paraíso. A Idade Média foi pródiga em narrativas nas quais seus autores afirmavam ter chegado às suas portas. A mais famosa dela, tomada em seu tempo como relato fidedigno, foi $A$ Viagem em torno da terra, de Mandeville, que jurava ter chegado aos seus muros. Depois descobriu-se que ele não tinha passado além da chamada Terra Santa. O resto era tudo a mais legítima e criativa ficção.

No século XVI, com as viagens ultramarinas, o paraíso voltou à ordem do dia. Era coisa tão fundamental no imaginário do viajante que rendeu copiosa literatura, bem lida por Sérgio Buarque de Hollanda, que se dedicou a análise exclusiva do topos, em obra aqui já citada, a que deu o belo título de Visão do paraíso.

Como se pode observar na descrição de Gândavo, não se trata de um lugar real, mas, antes de qualquer coisa, de um locus amoenus, tal como o concebia a literatura clássica. As palavras são fresco, delícia, regato, ribeira, temperança, todas recorrentes no arsenal de imagens bucólicas praticadas pelo classicismo, que viu a natureza como um cenário, que faria, séculos depois, Cláudio Manuel da Costa, travestido de Glauceste Saturnio, saudoso dos bosques coimbrãos, queixar-se da exuberância excessiva do Brasil, a impedir fazer poesia árcade ao modelo europeu, uma vez que em lugar de regatos a natureza brasileira oferecia rios barrentos e caudalosos; e em lugar de bosques frondosos, mato espesso e impenetrável. Foi necessária, como se sabe, uma reviravolta nas formulações árcades brasileiras para que tais aspectos, negativos, ganhassem, pelo nativismo, conotação positiva.

O simulacro do paraíso terreal não respondia a um anseio metafísico tão-somente. Já mostrei em texto anterior (LIMA, 2000), que a verdura permanente do trópico, tal qual aquela do paraíso, não só substitui uma imagem da natureza por outra como institui uma nova temporalidade, obrigando ao sucessivo do passar do tempo, caracterizado na mudança das estações, com seus extremos de calor e frio, dar lugar ao simultâneo de uma primavera eterna, estação ideal para celebrar a vida.

Se no hemisfério norte a primavera é momento de recomeço, despertar da natureza para a realização de um novo ciclo, no qual, porém, já se vislumbra o calor do verão e os frios do inverno, tão rigorosos que "ofendem" as plantas, nessas bandas da parte de baixo do Equador, ao contrário, a vida é sempre a festa do recomeço. Sem mudança à vista, o recomeço é fim em si mesmo, sem lugar para a ruína, de que tipo for. Eis, ao fim e ao cabo, o verdadeiro paraíso.

Mas o verdadeiro paraíso só pode ser assim concebido se nele houver lugar para o homem, destino final da criação de Deus. 
Esses moradores todos, em grande parte, tratam-se muito bem, e folgam com se ajudarem uns aos outros com seus escravos, e favorecem muito os pobres que começam a viver na terra. Isto geralmente é costume nestas partes, assim como outras muitas obras pias, por onde todos têm remédio de vida e nenhum pobre anda pelas portas a mendigar como nestes reinos (HSC, 74).

No caso desse paraíso - e não será o caso de todos eles? - o nome da felicidade é a ausência de escassez, conseguida - ou não se estaria no paraíso - á base da mais sonhada de todas as utopias humanas, a solidariedade total, enfatizada neste "isto geralmente é costume nestas partes”. O comentário opõe, assim, a província (de Santa Cruz) da plenitude ao reino da escassez, gerando um atrevido deslizamento semântico, que oporia o paraíso ao inferno, uma vez que é próprio deste a miséria - de todo tipo, sendo a mais visível dela a mendicância, mas, ao fim das contas, mera ponta de um iceberg, que fala mais da mesquinharia humana do que de si própria.

No paraíso, ao contrário, a mesquinharia e o egoísmo cederam lugar aos sentimentos ali exigidos para merecer dele ser morador. E são vividos festivamente, como se pode notar no verbo folgar. Não que se seja obrigado a praticar a bondade da divisão, mas tal é feita como deve ser no paraíso: com festiva alegria, de modo que a dor, esse traço infernal, seja uma desconhecida nesse mundo.

E como o paraíso não discrimina, ele é extensivo também ao nativo. Com toda disposição para não ver, Gândavo não consegue deixar de marcar o modo paradisíaco de viver do índio, em muito - em termos de paraíso, claro - superior ao do colono:

Mas a vida que buscam, e granjearia de que todos vivem, é a custa de pouco trabalho, e muito mais descansada que a nossa, porque não possuem nenhuma fazenda, nem procuram adquiri-la como os outros homens, e assim vivem livres de toda a cobiça e desejo desordenado de riquezas, de que as outras nações não carecem; e tanto que ouro nem prata, nem pedras preciosas têm entre eles nenhuma valia, nem para seu uso têm necessidade de nenhuma coisa destas, nem de outras semelhantes. Todos andam nus e descalços, tanto machos como fêmeas, e não cobrem parte alguma de seu corpo (HSC, 143).

Verdade que os portugueses, ao chegarem ao paraíso, aprenderam com ele a se comportar segundo suas regras básicas, mas não se pode esquecer donde vieram. Os índios, por sua vez, dele nunca saíram, daí as marcas diferenciais que tanto impressionaram o europeu - e o fizeram perceber existir efetivamente um paraíso do qual já tinham sido expulsos. A primeira delas é a ausência de necessidade de trabalho, garantida pela fartura abundante. Ora, se se pensar no aspecto moral e religioso que a idéia 
de trabalho implica, cristalizada na frase bíblica "ganharás o pão com o suor do teu rosto", o índio permanece no paraíso, de onde o trabalho está para sempre banido, por absoluta ausência de necessidade, diferente do português, que carrega o estigma do castigo, refém da transgressão praticada por seus antepassados. Por isso, ainda que no paraíso, esse recém-chegado jamais poderá usufruir de todas as suas benesses.

Dessa ausência, resulta, por conseguinte, a segunda, a ausência de cobiça, que faz do ouro e da pedra preciosa, pelos quais se mata e se morre, apenas mais um elemento a compor a natureza, cuja importância não será maior nem menor que uma outra e qualquer pedra, que um outro qualquer metal, pois todos têm o mesmo papel na harmonia do mundo. Atribuir valor a um determinado metal ou a uma pedra qualquer é somente degenerado esforço humano para construir paraísos artificiais, que, por artificiais, jamais o satisfarão, o que obrigará o homem a essa louca e insana corrida para lugar nenhum, cristalizada na idéia mesma de viagem.

E, por fim, a terceira marca do paraíso, a nudez, que tanto impressionou o viajante europeu, para quem a vestimenta já é parte do próprio corpo, que deve estar escondido para evitar-se a prática da luxúria, em razão da qual tanto se matou, tanto se morreu.

A nudez aponta para a inocência absoluta, estado no qual ainda não se formulou a idéia de vergonha por falta completa do que se envergonhar, pois não há interditos a demandarem transgressão. No paraíso, desejo e realização são ainda uma coisa só, coisa, infelizmente, a que o europeu já não pode aspirar, pois de há muito já não sabe o que é inocência, substituída então pela cobiça, pela luxúria, pela mesquinharia, esses sentimentos tão humanos que o fizeram, para sempre "bicho da terra, vil e pequeno", como bem o definiu Camões. Ou o "outro homem", como o chama Gândavo, já incapaz de merecer esse paraíso por inteiro. E se não pode merecê-lo, que ele seja humanizado, o que vale dizer, que ele seja destruído.

Se bem não tenha os extremos fantásticos do Peru, aquelas serras que confinam com o céu, a terra de Santa Cruz comporta mistérios. Por mais que se tenha esforçado para não se render a sua mágica, Gândavo não consegue deles esquivar-se - o que seria pedir muito ao viajante curioso das particularidades da terra. Por vezes, a curiosidade vai além do esperado, isto é, de um observador que luta por manter-se no plano da objetividade. É o que se dá, por exemplo, na descrição do São Francisco:

A partir da boca, o rio corre do sul para o norte; dentro é muito fundo e limpo e pode-se navegar por ele até sessenta léguas, como já se navegou. E daí por diante não se pode passar por causa de uma cachoeira mui grande, que há nesse passo, onde cai o 
peso da água de mui alto. E acima dessa cachoeira se mete o rio debaixo da terra e vem a sair daí a uma légua, e quando há cheias arrebenta por cima e arrasa toda a terra. Esse rio procede de um lago mui grande que fica no interior da província onde afirmam que há muitas povoações, cujos moradores (segundo a fama) possuem grandes haveres de ouro e pedrarias (HSC, 55).

Curioso, antes de tudo, é como o fantástico desborda da objetividade num contínuo, sem qualquer interrupção. Até o terceiro período vai-se muito bem, com três informações de caráter objetivo: a) a direção por onde corre o rio; b) sua fundura e navegabilidade e c) a presença da cachoeira (de Paulo Afonso). A seguir, contudo, sem qualquer aviso, adentra-se ao reino do fantástico, como se ainda se estivesse no plano do objetivo: acima da cachoeira o rio corre por baixo da terra.

Não é de estranhar que assim seja. A rigor, estranho é que se desse o contrário. Homem do seu tempo, Gândavo não tem como impedir tal contaminação. Que vem de longe, de muito longe ambas as idéias, tanto a do rio subterrâneo como a de ele nascer numa lagoa onde há ouro em abundância. Trata-se de referência, bastante corrente em seu tempo, dos quatro rios nascidos no paraíso terreal, o Nilo, o Ganges, o Tigre e o Eufrates, que, nascidos numa grande lagoa, de onde brotava quantidades imensas de ouro em pó, corriam juntos por sob a terra em longa extensão até se dividirem nos quatro rios conhecidos.

Para certificar-se de que o rio corria a céu aberto acima da cachoeira bastava apenas um pouco de alpinismo, mesmo porque, prova-o a mais elementar hidrologia, não há rios subterrâneos, pois a água não corre sob a terra. Ela apenas alimenta as fontes dos rios. Mas não valia a pena desmontar de modo tão rasteiro imagem tão preciosa, guardada carinhosamente no imaginário por tanto tempo. Era pragmatismo demasiado para um renascentista de extração medieval como aquele viajante português.

Se o olhar que vê é de importância fundamental para o alargamento do mundo, aquele outro, que não vê, tão ou mais importante que o primeiro, é o meio pelo qual se mantém algumas das verdades que norteiam o estar no mundo. E é por esse olhar que não vê que se vêem rios invisíveis; imaginários, sim, mas nem por isso menos reais, tão reais que, vez por outra, se dão a apresentar aos descrentes na forma dramática de cheias que a tudo "arrebenta por cima e arrasa toda a terra". Quanto mais não seja, para mostrar a pouca firmeza do chão que pisamos...

\section{$\operatorname{son}$}




\section{NOTAS}

1 As citações da História da província Santa Cruz a que vulgarmente chamamos Brasil foram extraídas da edição organizada por Sheila Hue \& Ronaldo Menegaz, que a chamaram de a Primeira História do Brasil. Elas virão acompanhadas da sigla HSC, seguida pelo número da página em que estão inseridas. As outras, relativas ao Tratado, de que se utilizou a edição organizada por Leonardo Dantas Silva, para que não se confundam os dois textos, trarão a sigla $T B$, seguida do número da página.

\section{REFERÊNCIAS}

AFFERGAN, Francis (1987). Exotisme et alterité. Paris, PUF.

CORTESÃO, Jaime (1990). Os descobrimentos portugueses. Lisboa, IN-CM.

GREENBLATT, Stephen (1996). Possessões maravilhosas. São Paulo. Edusp.

HOBSBAWN, Eric \& RANGER, Terence (2002). A invenção das tradições. 3ed. Rio de Janeiro, Paz e Terra.

HOLLANDA, Sérgio Buarque de (1992). Visão do paraíso. São Paulo, Brasiliense.

HUE, Sheila \& MENEGAZ, Ronaldo (Orgs.) (2004). A primeira História do Brasil- História da província Santa Cruz a que vulgarmente chamamos Brasil, de Pero de Magalhães de Gandavo. Rio de Janeiro, Jorge Zahar.

KAPPLER, Claude (1993). Monstros, demônios e encantamentos no final da Idade Média. São Paulo, Martins Fontes.

LIMA, Francisco Ferreira de (1998). O outro livro das maravilhas. Rio de Janeiro/Salvador, Relume Dumará/ Fundação Cultural do Estado da Bahia.

LIMA, Francisco Ferreira de (2000). Paraíso e Inferno na Bahia de Gabriel Soares de Sousa. Veredas - Revista da Associação Internacional dos Lusitanistas. (Vol. 03, Tomo I): 43-54, Porto, Portugal.

LIMA, Francisco Ferreira de (2001a). Quando o olho não vê: Gabriel Soares de Sousa e a permanência do fantasioso. In: DUARTE, Lélia Parreira (Org.) Encontros prodigiosos. Belo Horizonte, UFMG.

LIMA, Francisco Ferreira de (2001b). A retórica da sedução - Gabriel Soares de Sousa e o Tratado descritivo do Brasil. Convergência Lusíada, (18): 112-122, Rio de Janeiro, Gabinete Português de Leitura.

LIMA, Francisco Ferreira de (2004). Os atropelos do olhar: Caminha e as maravilhas de Santa Cruz. Légua \& Meia, (02): 126-138, Feira de Santana, PPGLDC.

LIMA. Luiz Costa (2006). História, Ficção, Literatura. São Paulo, Cia. Das Letras.

PESSOA, Fernando (1972). Obra poética. Rio de Janeiro, Aguillar.

PINTO, Fernão Mendes (1983). Peregrinação. Lisboa, IN-CM.

SILVA, Leonardo Dantas (Org.) (1995). Tratado da terra \& História do Brasil de Pero

de Magalhães de Gândavo. Recife, Fundação. Joaquim Nabuco/Massangana.

TODOROV, Tzvetan (1983). A conquista da América. São Paulo, Martins Fontes.

WHITE, Hayden (1992). Meta-História. São Paulo, Edusp. 
Gândavo: da objetividade e de suas traições

Gandavo: of objectivity and its treasons

\section{RESUMO}

Pero de Magalhães de Gândavo esteve no Brasil, provavelmente, entre 1558 e 1572. Dessa viagem resultou o Tratado da província do Brasil, que, numa versão posterior, ganharia o título de Tratado da terra do Brasil e, finalmente, numa terceira versão passaria a chamar-se História da provincia Santa Cruz a que vulgarmente chamamos Brasil. O projeto inteiro ocupou dez anos de sua vida. A hipótese levantada no artigo para justificar tanto título e tanto tempo de trabalho é a de que Tratado já não podia dar conta da grandeza e complexidade em que se transformara o Brasil, tarefa reservada à solenidade da História, que garantiria objetividade total, projeto, já se vê, fadado ao fracasso, posto ser o olhar freqüentemente traído pelo deslumbramento.

Palavras-chave: Identidade, alteridade, diferença

\section{ABSTRACT}

Pero de Magalhães de Gândavo stayed in Brazil sometime between 1558 and 1572. The result of this staying was the work Tratado da provincia do Brasil that later was entitled Tratado da terra do Brasil and, finally, in a third issue, it would be named História da provincia Santa Cruz a que vulgarmente chamamos Brasil. The whole Project took him ten years. In an attempt to justify not only the title but also so much work, the hipothesis supported by this article is that Tratado was not able to express all the greatness and complexity Brazil contained, a task left to the solemnity of Historia, what would guarantee total objectivity - a project, one might see, as failed, considering that eyeing is mostly betrayed by astonishment.

Keywords: Identity, otherness, difference

Recebido: 20/11/2007

Aprovado: 16/04/2008

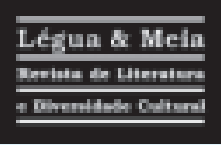

Lima, Francisco Ferreira de. Gândavo: da objetividade e de suas traições. Légua \& meia: Revista de literatura e diversidade cultural. Feira de Santana, UEFS, v. 6, no 4, 2008, p. 121-136.

Francisco Ferreira de Lima é doutor em Letras, Professor Pleno (titular) de Literatura Portuguesa na Universidade Estadual de Feira de Santana, tem vários artigos publicados em diversas revistas científicas, e é autor de O Outro livro das maravilhas (Rio de Janeiro: Relume Dumará, 1998) e O Brasil de Gabriel Soares de Sousa e outras viagens (Rio de Janeiro: 7Letras, 2009). 